\title{
PERENNIAL FORAGE GRASSES, FROM BREEDING TO HEALTHY RUMINANT FEED
}

\author{
D. Sokolović ${ }^{1}$, J. Radović ${ }^{1}$, Z. Tomić ${ }^{2}$ \\ ${ }^{1}$ Institute for Forage Crops, Globoder, 37251 Kruševac, Republic of Serbia \\ ${ }^{2}$ Institute for Animal Husbandry, Autoput 16, P. Box 23, 11080, Beograd-Zemun, Republic of Serbia \\ Corresponding author: dejan.sokolovic@ikbks.com \\ Invited paper
}

\begin{abstract}
Temperate forage grasses are the main components of grasslands occupying $40.5 \%$ of the world's terrestrial area and $30-40 \%$ of European agricultural area. They cover the land, providing a habitat and a source of food for domestic livestock, thus ensuring a supply of livestock products, with contributes to rural agricultural and economic development. Grasses are a natural food for ruminants. Rich in fibre, they provide the bulk necessary for good rumen function. Eaten at a sufficiently young stage, they are highly digestible and contain lot of energy. At this stage they also have high mineral and protein contents that cover a large part of animals' requirements. Grasslands usually produce the majority of the forage ingested by ruminant animals during grazing season. During winter housing grass hay and silage are often major parts of the staple diets. There are many improved grass genotypes in Serbia that share main characteristics: high yield and quality of dry matter within a target group of environments and in particular agricultural context. Beyond this common breeding goal there are vast of forage breeding programs as varied as the species upon which they are based and the breeders who develop and implement them. The intensification of forage production and utilization, especially during the second half of the twentieth century, led to a drastic reduction in the number of grass species in sown mixtures, as well as in permanent grasslands. Only a small number of species mainly the ryegrasses, timothy, cocksfoot and fescues are highly suited to intensive management. Moreover, in Europe from 1980 onwards, many forage systems were deintensified and wild or hardly selected species became more important in grasslands. Therefore, it is evident that importance of perennial grasses as animal feed will be increased in the future.
\end{abstract}

Key words: perennial grasses, forage yield, utilization, hay, silage 


\section{Introduction}

Grasses and grasslands in the world and Europe. Grass vegetation of different types occupies vast areas of world's land area. According to the World Resource Institute grasslands are among the largest ecosystems in the world (Suttie et al., 2005). The area is estimated at 52.5 millions $\mathrm{km}^{2}$ representing $40.5 \%$ of the terrestrial areas, excluding Greenland and Antarctica. In Europe (EU27) in 2007 permanent grasslands covered $60 \mathrm{Mha}$, or more than $75 \%$ of total acreage in grasslands and forage crops in Europe. In Western Europe grasslands occupy almost $40 \%$ of the agricultural area. In some countries or some regions the share of grasslands is higher (Ireland 76\%, Switzerland $72 \%$, United Kingdom 65\% and Austria 57\%). In Central and Eastern Europe (without Russia) in countries that previously had centrally planned agriculture, grasslands occupy only about $30 \%$ of agricultural area (data from 1999) (FAO, 2002). Historically grasslands played a major role in the agricultural development in most parts of Europe and represented crucial source of nutrients for livestock production, due the fact that they allow the utilization of marginal soils that are unsuitable for arable cropping. But over the last few decades, the area under the permanent grassland was dramatically decreased, with a 25\% reduction in France (Huyghe, 2010) mostly because of increase of abandoned areas and fields under annual forage crops. The situation has been slightly different over the last decade and in some countries areas under the grasslands remained stable or showed slightly decrease what results with not so severe decline in average. Nevertheless, it is foreseen that areas under the grasses will increase in the future, as the population's purchasing power for animal products increase and animal husbandry develops. In Serbia natural meadows cover large acreage over 1.45 million hectares, or almost $29 \%$ of total agriculture land (Stošić and Lazarević, 2009) while fields under the sown grasslands are on 150.000ha (Lazarević et al., 2005).

Main role and importance of perennial grasses. Perennial forage grasses represent very complex and heterogeneous group of cosmopolitan plants. On Balkan Peninsula and Serbia large species diversity of perennial grasses exists and many of them remained in refugio after last ice age. They are acclimatized to change of seasons and different habitats from lowlands with fertile deep soil to mountainous terrains over $1200 \mathrm{~m}$ a.s.l. with shallow soils and lack of nutrients and humus. Especially this broad adaptability to different agroecological and climatic conditions considerably increases agronomical importance of perennial grasses on the multiple bases.

The main fact is that they are the base components of grasslands and rangelands with more than 50\% of share (Vučković et al., 2005; Lazarević et al., 2005; Tomic et al., 2009). Demonstrating the importance of these species it is necessary to define many functions fulfilled by these two ecosystems. 
Firstly, they occupy the land, providing a habitat and a source of food for domestic livestock, thus ensuring a supply of livestock products, with contributes to rural agricultural and economic development (Stošić et al., 2005). In fact, grasses are a natural food for ruminants. Rich in fibre, they provide the bulk necessary for good rumen function. Grasses usually produce the majority of the forage ingested by ruminant animals during grazing season. During winter housing grass hay and silage are often major parts of the staple diets.

Furthermore, they are cenobionts and edificators of whole series of plant associations on natural meadows (Jovanović-Dunjić, 1983; Vučković, 2004; Tomić et al., 2005). State of biodiversity of grasses and grasslands in Serbia is still on high level including some meadow plant communities (Festuceto-Brometea) consisted of species representing about $42 \%$ of total flora in Serbia (DajićStevanović et al., 2010). Although all European grasslands are more or less modified by human activity and can be defined as "semi-natural", they have the best ecosystem quality of all possible agricultural production systems and provide undisturbed situation to species originally present in natural ecosystems (Reidsma et al., 2006). Therefore, preserving of biodiversity is one more contribution of perennial grasses and grasslands to environmental performance.

Also, grass ecosystems protect soil, water resources and natural habitat. Losses of nutrients and nitrate leaching may have very negative consequences on the groundwater quality and result in final in water pollution. With a crop of maize leaching of nitrogen reaches $100-200 \mathrm{~kg} \mathrm{~N}-\mathrm{NO} / \mathrm{ha}$ annually, while from a hay meadow the leaching is maintained at about $5 \mathrm{~kg} \mathrm{~N}-\mathrm{NO} 3 /$ ha annually (Le Gall et al., 1997). Perennial grasses form dense cover with haired root system which preserves soil from water runoff and reduce nitrate leaching by efficient consumption (Benoit and Simon, 2004) and also improve hydrological cycle and water quality. At the same time they show higher water infiltration rate than arable crops, reducing of rapid soil water evaporation and drying, and protect top soil from water and wind erosion. The older the grassland, the higher infiltration capacity, owing to a better soil structure, more earthworm burrows and a higher organic mater content. Grasses perenniality also determines the exploitation regime and sward persistency. Infrequent need for renovation relaxes the soil and reduces a significant part of the losses during ploughing.

\section{Specificity, directions and main criteria in perennial forage grasses improvement}

Grass genotypes (cultivars) have great influence on total yield and successful utilization of grasslands and therefore their improvement is very important issue. 
Scientifically based improvement and methodical breeding of perennial grasses, started last decade of the $19^{\text {th }}$ Century almost at the same time in Great Britain and USA. From that time grass breeding has been developed rapidly. The first long-lasting breeding programs on perennial forage grasses (especially Lolium perenne) were designed in Welsh Plant Breeding Station in Aberystwyth after its establishment 1919. In Serbia first steps in grass breeding happened considerable later than abroad, but still long time ago in the middle of last Century. In that time Institute for forage crops was established in Kruševac as specialized scientific institution for breeding and research of production technologies and utilization of forage crops. In such broad research area, breeding of perennial forage grasses takes central position and many cultivars bred in Kruševac were and still are main components of forage mixtures and animal fodder, especially in hilly-mountainous regions of Serbia.

Recently, breeders have been faced with many challenges and limitations in breeding programs. Some of those challenges, specified by Stuber (2001), thought almost decade old, but still current are identification of useful genetic parameters in diverse populations and lines, introgression of genes of interest in breeding germplasm, improvement of recurrent selection program based on phenotypic respond, investigation of heterosis and hybrid combining ability prediction, understanding and modification of interaction between genotype environment, genotype - genotype and genotype - pathogen. On the other hand, well known is that prediction of heritability (Sokolović et al., 2004b), genetic correlations (Sokolović et al., 2005), genetic gain (Sokolović, 2006) and interaction between genotype and environment are priceless in formulation of efficient strategy and breeding method.

However, all distinct forage grasses characteristics (especially perenniality and anemophily) make breeding of this group of plants extraordinary complex and species specific. Also breeding process is significantly longer than in other arable plants, resulting in hard and doubtful work more than decade long for releasing of cultivar.

Breeding of grasses in fact represents process which promising, but row material, transforms in to usable and productive genotype for certain system of forage production on grassland (Casler and van Santen, 2010). Therefore main compass (mechanism) which directs breeding of perennial forage grasses is way of utilization. Concerning grasses have been used dominantly in mixtures, breeders are directed to do breeding in real production conditions. This means breeding for different maturity to develop genotypes for new mixtures with different purposes and period of utilization. Also represents breeding to competitiveness with grasses and compatibility with legumes, because through breeding we should predict, monitor and stabilize dynamics of sward over time (Huyghe, 2010) especially in the installation period of sown multi-species grasslands (Korner et al., 2008). 
Increasing resistance and tolerance to drought by improvement of physiological and morphological traits (efficiency of plants to survive summer drought by dormancy) (Norton et al., 2007), water use and nutrients absorption efficiency, size and opening of stoma, root development and dept (Crush et al., 2007; Bonos et al., 2004) became most important breeding criteria, also.

Nevertheless, dry matter yield (DMY) is still represents "bottom line" of all breeding programs and most important characteristics of forage cultivars in Serbia. This criterion is undoubtedly part of all breeding schemes in perennial grasses, but small number of papers considered DMY breeding per se was published (Burton, 1982; Ceccarellii et al., 1980). Lot of breeding programs is aimed to improve different forage grasses traits (DMY components) showing height correlation coefficients with yield (Carlson, 1990; Sokolovic et al., 2003a; Sokolović, 2006). Also DMY improvement is achievable by developing polyploid cultivars of natural diploid forage grass species (Tomić and Popović, 1996), studying of interspecies hybridization, (Lolium-Festuca complex), for combining best traits of both species (Ghesquiere et al., 2010) and developing and identification for heterotic groups of most important grass species (Posselt, 2010a), for hybrid breeding (Poselt, 2003, 2010b), especially semi-hybrids and combination with synthetic breeding (Brummer, 1999; Scotti and Brummer, 2010). However, improvement of DMY per se is possible by breeding (Carlson, 1990), and progress in this trait breeding has been made in Serbia recent years (Sokolović et al., 2007, 2008). This is due to large genetic variability in breeding germplasm mostly formed from local populations (Sokolović et al., 2004c, 2006; Babić et al., 2010) and dominantly used breeding methods (phenotypic mass and recurrent selection). In Serbia this method has been used with slight modification after Burton (1982) which includes clone replication of chosen plant, eliminating fertilization with undesirable pollen and therefore enabling control of hybridization. This makes concentrations of "good" genes faster, shortening breeding cycle and recurrent selection in total.

Forage chemical composition also represent important breeding criterion and it is usually included in all forage grasses breeding programs. Improvement of crude protein content, fibre (ADF; NDF) and lignin (ADL) content (Claessens et al., 2005; Casler, 1999), DM digestibility or palatability (Casler and Carpenter, 1989) and WSC (Wilkins et al., 2003) by breeding is also possible and promising. In perennial grasses breeding in Serbia those traits were investigated and improved in all programs (Tomić et al., 2002; Sokolović et al., 2002; Ignjatović et al., 2004). Therefore perennial grasses breeding in Serbia has strong, 50 years long tradition especially in Institute for forage crops in Kruševac. As a result, 19 cultivars were created and released on Serbian market (Tomić and Sokolović, 2007) where they found large acceptance in local agro-ecological conditions. All domestic registered forage cultivars, according demanding testing and releasing process in network of micro field trials, have high genetic potential for production traits (Table 1.). 
Table 1. Forage cultivars of perennial grasses bred in Serbia and their achieved DMY (adapted from Sokolović et al., 2010)

\begin{tabular}{|c|c|c|c|}
\hline Grass species & Cultivar & $\begin{array}{l}\text { Year of registration } \\
\text { (re-registration) }\end{array}$ & $\begin{array}{l}\text { Dry matter yield }\left(\mathrm{t} \mathrm{ha}^{-1}\right) \\
\text { (data from different trials) }\end{array}$ \\
\hline \multirow{4}{*}{$\begin{array}{l}\text { Cocksfoot } \\
\text { Dactylis glomerata L. }\end{array}$} & K-6 & 1976 & $7.67-11.6$ \\
\hline & $\mathrm{K}-7$ & 1976 & $6.46-10.1$ \\
\hline & K-rana & 1992 & $9.12-10.44$ \\
\hline & $\mathrm{K}-40$ & 2001 & 10.59 \\
\hline \multirow{2}{*}{$\begin{array}{l}\text { Timothy } \\
\text { Phleum pratense } \mathrm{L} \text {. }\end{array}$} & K-15 & 1979 & $7.5-15.01$ \\
\hline & K-41 & 2002 & 10.56 \\
\hline \multirow{2}{*}{$\begin{array}{l}\text { Italian ryegrass } \\
\text { Lolium miltiflorum } \mathrm{L} .\end{array}$} & $\mathrm{K}-13$ & $1979(2006)$ & $10.36-14.07$ \\
\hline & $\mathrm{K}-29 \mathrm{t}$ & 1994 & 15.5 \\
\hline $\begin{array}{l}\text { Meadow fescue } \\
\text { Festuca pratensis Huds. }\end{array}$ & $\mathrm{K}-21$ & $1986(2007)$ & $11-11.5$ \\
\hline \multirow{3}{*}{$\begin{array}{l}\text { Tall fescue } \\
\text { Festuca arundinacea } \text { Schreb. }\end{array}$} & K-19 & 1982 & $13.3-17.72$ \\
\hline & $\mathrm{K}-20$ & $1982(2007)$ & $13.15-15.66$ \\
\hline & NS-10 & 1979 & 12.11 \\
\hline $\begin{array}{l}\text { Red fescue } \\
\text { Festuca rubra L. }\end{array}$ & $\mathrm{K}-14$ & $1979(2006)$ & $7.44-10.56$ \\
\hline \multirow{2}{*}{$\begin{array}{l}\text { Tall oatgrass } \\
\text { Arrhenatherum elatis (L.) P. } \\
\text { Beauv. Ex J. Presl \& C. Presl. }\end{array}$} & $\mathrm{K}-12$ & $1979(2006)$ & $8.23-12.46$ \\
\hline & K-16 & 2007 & $8.5-12.3$ \\
\hline $\begin{array}{l}\text { Perennial ryegrass } \\
\text { Lolium perenne } L .\end{array}$ & $\mathrm{K}-11$ & 2006 & 10.76 \\
\hline
\end{tabular}

They are characterized with high biomass production with good chemical composition in Serbian agro-ecological conditions (Sokolović et al., 2004a; Tomić et al., 2007), improved filed persistency and drought tolerance.

\section{Forage productivity and quality of perennial grasses}

On annual basis, in Europe, it is common for 50 to $75 \%$ of cattle and 90 to $95 \%$ of sheep fodder requirements to be met by grasslands because grasses are a natural food for ruminants.

Perennial grass leaves are broad and supple enough to be easily gripped by the mouth organs of cattle, sheep and goats and fine enough to be easily attacked by rumen micro-organisms. Rich in fibre, they provide the bulk necessary for good rumen function. Eaten at a sufficiently young stage, they are highly digestible and contain almost as much energy as cereal grains. At this stage they also have high mineral and protein contents that cover a large part of animals' requirements. Grass is above all a healthy food, usually free of residues or toxic substances.

Most of perennial grasses and their contemporary cultivars are highly productive and rich yield over 13 tha $^{-1}$ of dry matter (Sokolović et al., 2010) of excellent 
quality. Forage of most of perennial grasses species shows high digestibility (Wilkins, 1997), balanced NDF and ADF content (Casler, 2000) and crude protein content over $140 \mathrm{gkg}^{-1}$ (Tomić et al., 2007).

DMY of perennial grasses is easy improvable by application of fertilizers, especially nitrogen (Stošić et al., 2005), nevertheless this can influence on floristic composition and reduction of legume component in grasslands which is important for symbiotic $\mathrm{N}$ fixation from air and reduce transfer of $\mathrm{N}$ from legumes to grasses in mixture and possible over-yielding (Huyghe, 2010). Also potential risk of environment pollution by $\mathrm{N}$ leaching exists.

The final aim of exploiting grasses in agriculture is transformation of the herbage into livestock production. Thus meat and milk should not only meet society's needs in terms of quantity and feeding value, but should also bee free of toxic substances, have high organoleptic qualities and be produced according to ethical rules acceptable to society. Livestock products based on the utilisation of grasses are in an excellent position to meet these conditions. In this way grasslands and rangelands give high contribution to economic development.

\section{Utilization of forage perennial grasses}

Mixtures. Perennial grasses are components of mixtures where incorporated with other grasses and especially legumes show their best performance and forage yield. Perennial grass-legume mixtures of species with different ecological request for growing, enable utilization of vegetation space by horizontal and vertical direction and different ecological niches. Composition of the mixtures is determined by way of meadow utilization (grazing or cutting), planed duration of utilization (short term or long term mixtures), or dominated agroecological conditions in region of sowing. Usually mixtures have been formed from grass species which are competitive with each other and legume species which are compatible with used grasses. Only that way all positive characteristics of both plant group show maximum values. Grasses contribute in mixture with high DMY with lot of carbohydrates while legumes are fixing nitrogen from air and give protein component to the final herbage (Dinić et al., 2000).

Intensification of forage production and utilisation, especially during the second half of the twentieth century in Europe, led to a drastic reduction in the number of grass species in sown mixtures, as well as in permanent swards. Only a small number of species mainly the ryegrasses (perennial and Italian), timothy, cocksfoot and two fescues (tall and meadow) are highly suited to intensive management. The two Lolium species become dominant in the European seed trade (Kley, 1995) and in heavily nitrogen-fertilized swards in many regions. The interest in other species by farmers and agronomists decreased dramatically. However, some of the other grass species, for example Poa spp., bents Agrostis and meadow 
foxtail (Alopecurus pratensis), remained extremely widespread in low-input grasslands and rangelands and even in intensive permanent grasslands. Considering European permanent grasslands as a whole, many grass species arte still much more abundant than the two Lolium species and therefore their contribution to animal feeding is also more important. Moreover, in Europe from 1980 onwards, many forage systems were deintensified for several reasons and wild or littleselected species became more important in such systems.

Grazing. Over Europe grasslands and rangelands usually produce the majority of the forage ingested by ruminant animals during grazing season. The key factor in grazing of grasses is high allowance of highly digestible forage due to frequent defoliation. Also it is the best, most economical, and for ruminants healthiest way of diet and utilization of grasses during vegetation season.

But there are differences between grassland production systems in different part of Europe. Due to fact that role of grasslands in livestock farming in Europe is connected to both socio-economic and natural conditions, Europe is divided into different regions according geographic and climatic characteristics (Pflimlin and Todorov, 2003). The hilly and mountainous Mediterranean, Balkan and Nordic regions are characterised with unfavourable soil and climatic conditions and extensive livestock farming with dominant role of grazing, resulting with low use and pressure on sources. Even process of grassland abandonment and forestation is quite present.

On the contrary in north-west Europe intensive dairy farming is driven by a combination of grassland, forage crops and supplements with concentrates. During the previous period the role of grazing was diminishing constantly.

From an economic point of view grazed grasslands and perennial grasses continue to be the cheapest forage, but it takes good managerial skills to produce and to offer constant high quality of grazed grass.

Grazed grasses must be able to produce high-quality forage within the environmental constrains, at a low cost, with a high labours efficiency and an acceptable comfort for the farmer representing the three pillars of the sustainability (Van den Pol-van Dasselaar et al., 2008).

\section{Perennial forage grasses biomass conservation}

Grasses stored as hay and silage provides feed for livestock during periods when pasture growth is insufficient and for use in confinement feeding systems. Also use of preserved grasses as a feed supplement may result in greater animal production levels than grazed forage alone (Philips and Leaver, 1985).

In Serbia during winter housing grass hay and silage are often major parts of the staple diets. The process involved in grass field conservation and storage of 
both hay and silage generally reduce both forage yield and quality compared with the standing crop.

Hay. Traditional method of perennial grasses and grasslands conservation is hay making, usually through three or less cuts depending on climatic condition during year and grassland altitude. This is process which initial grass moisture of about $800 \mathrm{gkg}^{-1}$ reduces to $500 \mathrm{gkg}^{-1}$ within 13 to 40 hours depending on grass species (Jones, 1991). This way of grassland utilisation by cutting, beside advantages as technically and financially less demandable (low number of simple agriculture operation with usual machinery), it is characterised by many losses on production field and during storage. Losses during forage hay harvest may include mechanical losses due to moving, conditioning, raking, packaging, baling and handling as well as respiration and leaching (Pitt, 1982). Mechanical losses are directly correlated with hay moisture and raise to over $15 \%$ with dry matter moisture drop on $150 \mathrm{gkg}^{-1} \mathrm{DM}$ (McGechan, 1989).

Also hay quality is usually questionable because common time of grassland cutting is to late over year, when grasses are to mature or weather is not favourable for grass field drying. Improvement of utilisation time of natural grasslands would significantly improve hay quality and palatability.

Silage. Ensiling of perennial grasses represent most suitable way of forage conservation which allow maximizing of quantity and quality of produced voluminous animal feed due to reduction of loses in yield and DM quality during traditional hay making. It also ensures quality feed during whole year, especially throughout winter period of staple keeping of animals. Therefore silage technology is very significant, because herbal material can be conserved with high content of humidity, but wilting of cut biomass (Dinić et al., 2002, 2008) helps to provide better conditions for lactic acid fermentation, provides one class better quality silage and reduces loss of $\mathrm{CP}$. Moved in right phase of beginning of tillering grasses biomass is characterized with 150 to $190 \mathrm{gkg}^{-1}$ of crude protein, $330 \mathrm{~g} \mathrm{~kg}^{-1}$ $\mathrm{ADF}$ and $700 \mathrm{gkg}^{-1} \mathrm{NDF}$ (Dinić et al., 2003, 2010).

Perennial grasses are much more suitable for ensiling than perennial legumes, because they have favourable water soluble carbohydrates and buffer capacity ratio over 4 or 5 (Dinić et al., 2008). Therefore perennial grasses biomass is excellent supplement for successful ensiling of legumes biomass (Dinić et al., 2000) what is one more reason for sowing of grass legume mixtures.

\section{Other benefits from perennial grasses}

Besides main profit from perennial forage grasses in animal feeding there are also few very important gains from grasses and grasslands. A grass cover also allows good infiltration of water into the soil, much better than other vegetation like crops and dense coniferous forest and protects the soil since the grasses and 
their root systems limit water and wind erosion. Rangeland and cutting grasslands protect the quality of surface water and groundwater tables, because water that infiltrates the soil from such a cover contains little or no pesticides or nitrates, unlike cropland (Benoit, 1994; Thelier-Huche et al., 1994). On grasslands none or very small amounts of pesticides are used so the risk of pollution of groundwater by such substances is limited.

Grasses, especially perennial, are large harbour with approximately $34 \%$ of the global stock of carbon in terrestrial ecosystems, while in comparison, forest ecosystems store about 39\% and arable ecosystems 17\% (Pedro Silva et al., 2008). Consequently grasses biomass as a large source of carbon can be used as a renewable source of energy for combustion, or converted in bio-fuel or digested in bio-gas.

Nevertheless ley-arable rotation with short term sown grasslands incorporated is an essential part of the organic farming systems in order to accumulate soil organic matter and to provide nutrients to the following crop, as well as to help control of weeds and diseases (Reheul et al., 2010).

In addition, some of them (perennial ryegrass, red, tall and other fescues, Kentucky bluegrass, bent grasses) are main components of amenity grasslands of northern and temperate climate. Market of that seed have became largest grass seed market in the world recent years.

Finally, the diversity of environments and types of community in grasslands is immense. They provide diverse habitats for many different forms of wildlife and low productivity extensive grasslands are extremely valuable as home for many specialized plants, fungi, insects, mammals and other animal species (Bernhardt et al., 2010). This is a feature that can be of great importance for natural heritage and genetic diversity.

\section{Conclusion}

Grass vegetation of different types occupies vast areas of world's terrestrial area and $30-40 \%$ of European agricultural area. Perennial forage grasses represent very complex and heterogeneous group of cosmopolitan plants. They occupy the land, providing a habitat and a source of food for domestic livestock ruminants as their natural food, thus ensuring a supply of livestock products, what contributes to rural agricultural and economic development.

Perennial grasses breeding in Serbia has strong, 50 years long tradition especially in Institute for forage crops in Kruševac and as a result, 19 cultivars were created and released on Serbian market. Most of perennial grasses and their contemporary cultivars are highly productive and rich yield over 13 tha $^{-1}$ of dry matter of excellent quality. 
The final aim of exploiting grasses in agriculture is transformation of the herbage into livestock production. From an economic point of view grazed grasslands and perennial grasses continue to be the cheapest forage, but grasses stored as hay and silage provides feed for livestock during periods of winter housing. Besides main profit from perennial forage grasses in animal feeding there are also few very important gains from grasses and grasslands like water and soil protection, biodiversity preservation, bio-fuel, amenity use and contribution to the rotational system. Therefore, it is evident that importance of perennial grasses as animal feed and in other aspects also, will be increased in the future.

\title{
Acknowledgment
}

Presented results were obtained through Project TR 31057 funded by Ministry of Education and Science of the Republic of Serbia.

\section{Višegodišnje krmne trave, od oplemenjivanja do zdrave hrane za preživare}

\author{
D. Sokolović, J. Radović, Z. Tomić
}

\section{Rezime}

Krmne trave umerenog klimata su glavne komponente travnjaka koji se prostiru na 40,5\% svetskog kopna, odnosno na 30 do $40 \%$ poljoprivrednog zemljišta u Evropi. Višegodišnje trave pokrivaju zemljište, obezbeđujući stanište i izvor hrane za domaće životinje i na taj način unapređuju stočarsku proizvodnju i doprinose ruralnom razvoju sa poljoprivrednog i ekonomskog aspekta. Trave su prirodna hrana za preživare. Pošto su bogate celulozom, obezbeđuju kabastu komponentu neophodnu za pravilnu funkciju rumena preživara. Ako se konzumiraju u ranijoj fazi, visoko su svarljive i sadrže puno energije. U toj fazi takođe imaju visok nivo minerala i proteina što zadovoljava veliki deo potreba domaćih životinja. Travnjaci obično produkuju veći deo krme konzumirane od strane preživara tokom sezone ispaše. Tokom čuvanja preživara u stajama, seno i silaža od višegodišnjih trava su najbitniji deo obroka. Sve domaće sorte višegodišnjih trava u Srbiji karakterišu visoki prinosi i kvalitet dobijene biomase u lokalnim agroekološkim uslovima i u različitim sistemima iskorišćavanja. Pored ovih osobina koje predstavljaju esencijalne oplemenjivačke ciljeve postoji dosta različitih programa selekcije koji se razlikuju usled različitosti vrsta višegodišnjih trava i kriterijuma oplemenjivanja. 
Intenziviranje proizvodnje i iskorišćavanja krmnog bilja posebno tokom druge polovine 20. veka vodilo je drastičnom redukovanju broja vrsta trava $u$ sejanim smešama kao i na prirodnim travnjacima. Samo je mali broj vrsta kao što su ljuljevi, mačji rep, ježevica i vijuci bio podesan za intenzivan način iskorišćavanja travnjaka. Međutim od 1980 pa na ovamo u Evropi su mnogi sistemi proizvodnje krmnog bilja deintenzivirani, pa divlje i ostale vrste selekcionisanh višegodišnjih trava dobijaju na značaju. Primetno je da će zastupljenost travnjaka i značaj višegodišnjih trava kao stočne hrane rasti u budućnosti rastom tražnje za stočarskim proizvodima i rastom kupovne moći i standarda ljudskog društva u celini.

\section{References}

BABIĆ S., SOKOLOVIĆ D., RADOVIĆ J., ANĐELKOVIĆ B., ŽIVKOVIĆ B. (2010): Varijabilnost najvažnijih osobina autohtonih populacija lisičjeg repa (Alopecurus pratensis L.) i bezosnog vlasena (Bromus inermis Leyss.). Zbornik radova XV savetovanja o biotehnologiji, Čačak, 15, 16, 129-134.

BENOIT M. (1994): Water pollution risk in grassland and arable land. Fourrages, $140,407-420$.

BENOIT M., SIMON J.C. (2004): Grassland and water resources: recent findings and challenges in Europe. Grassland Sci. Eur., 9, 117-128.

BERNHARDT K.G., LAPIN K., WERSCHONIG E. (2010): The future of plant diversity in grassland farming vegetation - a review of diversity in a strongly transformed agricultural landscape. Biotechnology in Animal Husbandry, 26, spec. issue, 205-217.

BONOS A., DEBRA R., HIGNIGHT K., MEYER W.A. (2004): Selection for deep root production in tall fescue and perennial ryegrass. Crop Sci., 44, 5, 1770-1775.

BRUMMER E.C. (1999): Capturing heterosis in forage crop cultivar development. Crop Sci., 39, 943-954.

BURTON G.W. (1982): Improved recurrent restricted phenotypic selection increases bahiagrass forage yields. Crop Sci., 22, 1058-1061.

CARLSON I.T. (1990): Direct and indirect selection for forage yield in reed canarygrass. Agronomy abstracts, ASA, Madison, WI., 83-84.

CASLER M.D. (1999): Phenotypic recurrent selection methodology for reducing fibre concentration in smooth bromegrass. Crop Sci., 39, 381-390.

CASLER M.D. (2000): Breeding forage crops for increased nutritional value. Adv. Agron., 71, 51-107.

CASLER M.D., CARPENTER J.A. (1989): Morphological and chemical responses to selection for in vitro dry matter digestibility in smooth bromegrass. Crop Sci., 29, 924-928. 
CASLER M.D., VAN SANTEN E. (2010): Breeding objectives in forages. In: BOLLER B., POSSELT U., VERONESI F. (eds), Fodder crops and amenity grasses. Springer, 115-136.

CECCARELLI S., FALCINELLI M., DAMIANI F. (1980): Selection for dry matter yield in Lolium perenne L. I Direct response to selection. Can. J. Plant Sci., 60, 491-500.

CLAESSENS A.R., MICHAUD R., BELANGER G., MATHER D.E. (2005): Leaf and steam characteristics of timothy plants divergently selected for the ratio of lignin to cellulose. Crop Science, 45, 2425-2429.

CRUSH J.R., EASTON H.S., WALLER J.E., HUME D.E., FAVILLE M.J. (2007): Genotypic variation in patterns of root distribution, nitrate interception and response to moisture stress of a perennial ryegrass (Lolium perenne L.) mapping population. Grass and Forage Science, 62, 265-273.

DAJIĆ-STEVANOVIĆ Z., LAZAREVIĆ D., PETROVIĆ M., AĆIĆ S., TOMOVIĆ G. (2010): Biodiversity of natural grasslands of Serbia: State and prospects of utilization. Biotechnology in Animal Husbandry, 26, spec. issue, 235-247. DINIĆ B., ĐORĐEVIĆ N., LAZAREVIĆ D., IGNJATOVIĆ S., LUGIĆ Z. (2000): Uticaj udela crvene deteline i italijanskog ljulja na kvalitet i hranljivu vrednost silaže. Arhiv za poljoprivredne nauke, 61, 213, 171-181.

DINIĆ B., ĐORĐEVIĆ N., LAZAREVIĆ D., STOŠIĆ M., IGNJATOVIĆ S. (2002): Uticaj faze razvića i nivoa suve materije na kvalitet zelene mase i silaže italijanskog i engleskog ljulja. Biotehnologija u stočarstvu, 18, 5-6, 265-273.

DINIĆ B., LAZAREVIĆ D., IGNJATOVIĆ S., ĐORĐEVIĆ N. (2003): The influence of development phase and dry matter level on quality and nutritive value of orchard grass silage. Procc. of $11^{\text {th }}$ International scientific symposium "Forage conservation", $9^{\text {th }}-11^{\text {th }}$ September, Nitra, Slovak Republic, 130-132.

DINIĆ B., ĐORĐEVIĆ N., SOKOLOVIĆ D., LAZAREVIĆ D., CVETKOVIC M. (2008): Tall oatgrass (Arrhenatherum elatius) silage quality dependence on stage of growth and wilting. Procc. of $13^{\text {th }}$ International conference "Forage conservation", $3^{\text {rd }}-5^{\text {th }}$ September, Nitra, Slovak Republic, 126-127.

DINIĆ B., RADOVIĆ J., JEVTIĆ G. (2010): Procedures for improvement of the quality of fermentation process and increase of nutritive value of silages. Biotechnology in Animal Husbandry, 26, spec. issue, 261-274.

FAO (2002): FAOSTAT Agriculture data - Land Use (available at: http://apps.fao.org/page/collections?subset=agriculture)

GHESQUIERE M., HUMPHREYS M.W., ZWIERZYKOWSKI Z. (2010): Festulolium. In: BOLLER B., POSSELT U., VERONESI F. (eds), Fodder crops and amenity grasses. Springer, 293-316.

HUYGHE C. (2010): Grasslands and forage crops in Europe: Context and stakes. Consequences for breeding. Biotechnology in Animal Husbandry, 26, spec. issue, 118.

IGNJATOVIĆ S., SOKOLOVIĆ D., JEVTIĆ G., VASIĆ T. (2004): Uticaj starenja na hemijski sastav višegodišnjih trava. Acta Ariculturae Serbica, IX, 17, 325-329. 
JONES L. (1991): Laboratory studies on the effect of potassium carbonate solution on the drying of cut forage. Grass Forage Sci., 46, 153-158.

JOVANOVIĆ-DUNJIĆ R. (1983): A contribution to the study of composition and structure of the meadow community Arrhenatheretum elatiorus in the mountain Veliki Jastrebac region. Arhiv bioloških nauka, 35, 1-2, 51-65.

KLEY G. (1995): Seed production in grass and clover species in Europe. Proceedings of the $3^{\text {rd }}$ International Herbage Seed Conference, Germany, 12-22.

KORNER C., STOCKLIN J., REUTHER-THIEBAUD L., PELAEZ-RIEDL S. (2008): Small differences in arrival time influence composition and productivity of plant communities. New Phytologist, 177, 698-705.

LAZAREVIĆ D., STOŠIĆ M., LUGIĆ Z., TERZIĆ (2005): The importance of sown grasslands and share of legume species in the mixtures for the livestock production. Biotechnology in Animal Husbandry, 21, 5-6, 273-280.

LE GALL A., LEGARTO J., PFIMLIN A. (1997): Place of maize and grassland in the dairy forage systems. III Impact on the environment. Fourrages, 150, 147-169. MCGECHAN M.B. (1989): A review of losses arising during conservation of grass forage: I Field losses. J. agric. Eng.Res., 44, 1-21.

NORTON M.R., VOLAIRE F., LELIEVRE F. (2007): Measuring summer dormancy in temperate perennial grasses. Proceedings of EUCARPIA fodder crops and amenity grasses section and Medicago spp. Group joint Meeting, Perugia, Italy, 353-356.

PEDRO SILVA J., TOLAND J., JONES W., ELDRIDGE J., THORPE E., O'HARA E. (2008): LIFE and Europe's grasslands: restoring a forgotten habitat. DG environment of the EU, 54.

PITT R.E. (1982): A probability model for forage harvesting systems. Trans. Am. Soc. Agric. Eng., 25, 549-562.

PFLIMLIN A., TODOROV N.A. (2003): Trends in European forage sistems for meat and milk production: facts and new concerns. Grassland Sci. Eur., 8, 1-10.

PHILLIPS C.J.C., LEAVER J.D. (1985): Supplementary feeding of forage to grazing dairy cows. Offering hay to dairy cows at high and low stocking rates. Grass. Forage Sci., 40, 183-192.

POSSELT U.K. (2003): Heterosis in grasses. Czech J. Genet. Plant Breed., 39, 48-53. POSSELT U.K. (2010a): Identification of heterotic patterns in perennial ryegrass. In: HUYGHE C. (ed.), Sustainable use of genetic diversity in forage and turf breeding. Springer, 569-572.

POSSELT U.K. (2010b): Alternative breeding strategies to exploit heterosis in forage crops. Biotechnology in animal husbandry, 26, spec. issue, 49-66.

REHEUL D., DE CAUWER B., COUGNON M. (2010): The role of forage crops in multifunctional agriculture. In: BOLLER B., POSSELT U., VERONESI F. (eds), Fodder crops and amenity grasses. Springer, 1-12.

REIDSMA P., TEKELENBURG T., VAN DER BERG M., ALKEMADE R. (2006): Impact of land use change on biodiversity: an assessment of agricultural biodiversity in the European Union. Agric. Ecosyst. Environ., 114, 86-102. 
SCOTTI C., BRUMMER E.C. (2010): Creation of heterotic groups and hybrid varieties. In: HUYGHE C. (ed.), Sustainable use of genetic diversity in forage and turf breeding. Springer, 509-518.

SOKOLOVIĆ D. (2006): Genetička dobit u procesu oplemenjivanja engleskog ljulja (Lolium perenne L.). Doktorska disertacija, Poljoprivredni fakultet Zemun Beograd, 1-133.

SOKOLOVIĆ D., TOMIĆ Z., IGNJATOVIĆ S., ŠURLAN-MOMIROVIĆ G., ŽIVANOVIĆ T. (2002): Genetic variability of perennial ryegrass (Lolium perenne L.) autochthonous populations. II. Dry mater yield and chemical composition. Grasslands Science in Europe, 7, 92-93.

SOKOLOVIĆ D., TOMIĆ Z., LUGIĆ Z. (2003a): Dry matter yield components of perennial ryegrass (Lolium perenne L.) populations. Grasslands Science in Europe, $8,126-130$.

SOKOLOVIĆ D., IGNJATOVIĆ S., TOMIĆ Z. (2004a): Prinos i kvalitet krme eksperimentalnih genotipova višegodišnjih trava. Acta Agriculturae Serbica, 17, 135-142.

SOKOLOVIĆ D., LUGIĆ Z., RADOVIĆ J. (2004b): Varijabilnost i heritabilnost nekih osobina genotipova engleskog ljulja (Lolium perenne L.). Zbornik izvoda III kongresa genetičara Srbije, Subotica, 150.

SOKOLOVIĆ D., RADOVIĆ J., IGNJATOVIĆ S. (2004c): Study of morphological traits and yield of tall oatgrass population from Serbia. Grasslands Science in Europe, 9, 437-439.

SOKOLOVIĆ D., IGNJATOVIĆ S., TOMIĆ Z. (2005): Variability and correlations of some investigated traits of perennial ryegrass populations. Proceedings of XX International Grassland Congress, Dublin, Ireland and UK, 125.

SOKOLOVIĆ D., RADOVIĆ J., LUGIĆ Z., TOMIĆ Z., BABIĆ S. (2006): Genetic variability of perennial ryegrass (Lolium perenne L.) autochthonous populations. III. Seed yield and seed yield components. Procc. of $26^{\text {th }}$ EUCARPIA Fodder Crops and Amenity Grasses Section Meeting, Perugia, Italy, 253-256.

SOKOLOVIĆ D., LUGIĆ Z., RADOVIĆ J., TOMIĆ Z., BABIĆ S., VUČKOVIĆ M. (2007): Agronomska svojstva nove sorte engleskog ljulja Kruševački 11 (K11). Zbornik radova Instituta za ratarstvo i povrtarstvo Novi Sad, 169-175. SOKOLOVIĆ D., LUGIĆ Z., RADOVIĆ J., TOMIĆ Z., BABIĆ S., MARKOVIĆ J., MILENKOVIĆ J. (2008): Agronomske osobine nove sorte francuskog ljulja Kruševački 16 (K-16). Zbornik abstrakata V naučno-stručnog Simpozijuma iz selekcije i semenarstva, Vrnjačka Banja, 133.

SOKOLOVIĆ D., TOMIĆ, Z., BABIĆ S. (2010): Perennial forage grasses breeding in Serbia: Achievements limits and prospects. Biotechnology in Animal Husbandry, 26, spec. issue, 91-106.

STOŠIĆ M., LAZAREVIĆ D., DINIĆ B., TERZIĆ D., SIMIĆ A. (2005): Natural grasslands as basis of livestock development in hilly-mountainous regions of Central Serbia. Biotechnology in Animal Husbandry, 21, 5-6, 265-272. 
STOŠIĆ M., LAZAREVIĆ D. (2009): Country Pasture/Forage Resource Profiles: Serbia and Montenegro

http://www.fao.org/ag/AGP/AGPC/doc/Counprof/serbia/serbia.htm\#9contacts. STUBER C.W (2001): Breeding multigenic traits. p. 115-137. In: PHILLIPS R.L., VASIL I.K. (eds), DNA-based markers in plants. Kluwer Academic Publishers. SUTTIE J.M., REYNOLDS S.G., BATELLO C. (2005): Grasslands of the world. FAO, plant production and protection services, 34, 514.

THELIER-HUCHE L., SIMON J.C., LE CORRE L., SALETTE J. (1994): Use of organic and mineral fertilisation on grassland and maize. Long term study. Fourrages, 138, 145-155.

TOMIĆ Z., POPOVIĆ J. (1996): Tetraploidna sorte italijanskog ljulja (Lolium multiflorum Lam.) KRUŠEVAČKI 29 tetra, Zbornik radova Instistuta za ratarstvo i povrtarstvo, sveska 26 , Novi Sad, 89-96

TOMIĆ Z., SOKOLOVIĆ D., IGNJATOVIĆ S., ŽUJOVIĆ M., NEGOVANOVIĆ D, KRNJAJA V., NEŠIĆ Z., VORKAPIĆ M. (2002): Chemical composition of domestic and foreign cultivars of perennial grasses according to cuts for animal. Biotechnology in Animal Husbandry, 18, 5-6, 251-256.

TOMIĆ Z., NEŠIĆ Z., MRFAT-VUCKOVIC S., ŽUJOVIĆ M. (2005): Quality and plant associations structure of grasslands on Stara planina mountain. Biotechnology in Animal Husbandry, 21, 5-6, 253-258.

TOMIĆ Z., SOKOLOVIĆ D. (2007): Oplemenjivanje višegodišnjih trava metode, kriterijumi i rezultati u Srbiji. Zbornik radova Instituta za ratarstvo i povrtarstvo, Novi Sad, vol. 44, No. I, 51-69.

TOMIĆ Z., LUGIC Z., RADOVIC J., SOKOLOVIĆ D., NEŠIĆ Z., KRNJAJA V. (2007): Perennial legumes and grasses stable source of quality livestock fodder feed. Biotechnology in Animal Husbandry, 23, 5-6, 559-572.

TOMIĆ Z., BIJELIC Z., ŽUJOVIĆ M. (2009): Analysis of grassland associations of Stara planina mountain. Biotechnology in Animal Husbandry, 25, 5-6, 451-464.

VAN DEN POL-VAN DASSELAAR A., VELLINGA T.V., JOHANSEN A., KENNEDY E. (2008): To graze or not to graze, that's the question. Grassland Sci. Eur., 13, 706-716.

VUČKKOVIĆ S. (2004): Travnjaci. Poljoprivredni fakultet, Zemun - Beograd, 1454-488

VUČKOVIĆ S., SIMIĆ A., ĐORĐEVIC N. (2005): Relationship between forage yield and quality of Cinosuretum cristati type meadows and different rates of nitrogen fertilizer. Biotechnology in Animal Husbandry, 21, 5-6, 293-296.

WILKINS P.W., LOWAT A.J., JONES M.L. (2003): Improving annual yield of sugar and crude protein by recurrent selection within diploid ryegrass breeding population, followed by chromosome doubling and hybridization. Czech J. Genet. Plant Breed., 39, 95-99. 